\title{
Refuge
}

Canada's Journal on Refugees

Revue canadienne sur les réfugiés

\section{Fostering Better Integration Through Youth-Led Refugee Sponsorship}

\author{
Carolyn McKee, Lee-Anne Lavell, Michelle Manks and Ashley Korn
}

Volume 35, Number 2, 2019

Private Sponsorship in Canada

URI: https://id.erudit.org/iderudit/1064821ar

DOI: https://doi.org/10.7202/1064821ar

See table of contents

Publisher(s)

Centre for Refugee Studies, York University

ISSN

0229-5113 (print)

1920-7336 (digital)

Explore this journal

Cite this article

McKee, C., Lavell, L.-A., Manks, M. \& Korn, A. (2019). Fostering Better Integration Through Youth-Led Refugee Sponsorship. Refuge, 35(2), 74-85. https://doi.org/10.7202/1064821ar
Article abstract

World University Service of Canada (WUSC) participates in private sponsorship as a sponsorship agreement holder through its Student Refugee Program. More than ninety campus-based constituent groups known as WUSC Local Committees resettle approximately 130 refugee students to Canadian post-secondary institutions each year. This article seeks to assess the effectiveness of the Student Refugee Program's youth-to-youth sponsorship model in integrating former refugees into their receiving communities. We outline the impact of the Student Refugee Program upon its beneficiaries, the important role youth volunteers play in supporting their integration and building more welcoming communities for newcomers in Canada, and the effect of the program on receiving societies. We conclude with recommendations for scaling up the program in Canada and sharing the model internationally.
Copyright (c) Refuge: Canada's Journal on Refugees, 2019

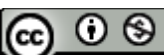

This document is protected by copyright law. Use of the services of Érudit (including reproduction) is subject to its terms and conditions, which can be viewed online.

https://apropos.erudit.org/en/users/policy-on-use/ 


\title{
Fostering Better Integration through Youth-Led Refugee Sponsorship
}

\author{
CAROLYN MCKEE, LEE-ANNE LAVELL, MICHELLE MANKS, and ASHLEY KORN
}

\section{Abstract}

World University Service of Canada (wUSC) participates in private sponsorship as a sponsorship agreement holder through its Student Refugee Program. More than ninety campus-based constituent groups known as wUSC Local Committees resettle approximately 130 refugee students to Canadian post-secondary institutions each year. This article seeks to assess the effectiveness of the Student Refugee Program's youth-to-youth sponsorship model in integrating former refugees into their receiving communities. We outline the impact of the Student Refugee Program upon its beneficiaries, the important role youth volunteers play in supporting their integration and building more welcoming communities for newcomers in Canada, and the effect of the program on receiving societies. We conclude with recommendations for scaling up the program in Canada and sharing the model internationally.

\section{Résumé}

Entraide universitaire mondiale du Canada prend part au parrainage privé en tant que Signataire d'entente de parrainage à travers son Programme détudiantes et détudiants réfugiés. Plus de 90 comités locaux sur les campus réinstallent approximativement 130 étudiants réfugiés dans des institutions postsecondaires canadiennes chaque année. Cet article cherche à évaluer l'efficacité du modèle de parrainage par et pour les jeunes du Programme détudiantes et détudiants réfugiés à intégrer d’anciens réfugiés dans leurs communautés de réception. Nous présentons l'impact du Programme d'étudiantes et d'étudiants réfugiés sur ses bénéficiaires, le rôle important que les jeunes bénévoles jouent afin de soutenir leur intégration et construire des communautés plus accueillantes pour les nouveaux arrivants au Canada, ainsi que l'effet du programme sur les universités d'accueil. En conclusion, nous présentons des recommandations pour améliorer le programme au Canada et partager le modèle à l'international.

\section{Introduction}

$\mathrm{I}$ $n$ recent years, the global refugee crisis has pushed public discourse on refugee and migrant issues into the spotlight in Canada and around the world. Since 2015, more than 107,245 refugees were resettled to Canada through different channels. ${ }^{1}$ Refugees are resettled to Canada directly (c) Carolyn McKee, Lee-Anne Lavell, Michelle Manks, and Ashley Korn, 2019. This open-access work is licensed under a Creative Commons Attribution-NonCommercial 4.0 International Licence, which permits use, reproduction, and distribution in any medium for non-commercial purposes, provided the original authorship is credited and the original publication in Refuge: Canada's Journal on Refugees is cited.
Cette œuvre en libre accès fait lobjet d'une licence Creative Commons Attribution-NonCommercial 4.o International License, laquelle autorise l'utilisation, la reproduction et la distribution de l'œuvre sur tout support à des fins non commerciales, pourvu que l'auteur ou les auteurs originaux soient mentionnés et que la publication originale dans Refuge: revue canadienne sur les réfugiés soit citée. 
from overseas contexts ${ }^{2}$ through three programs: the Government Assisted Refugees Program, the Blended Visa Office-Referred Program, and the Private Sponsorship of Refugees Program (PSRP). ${ }^{3}$ This article will focus on the last.

The PSRP provides an opportunity for Canadians and permanent residents to become actively involved in the resettlement of refugees. The program is a partnership between the government of Canada, the government of Quebec, and groups that decide to offer sponsorship to a refugee or refugees. These groups include faith-based groups, groups of five or more individuals, or community associations. Under the PSRP, Immigration, Refugees and Citizenship Canada (IRCC) facilitates refugees' arrival in Canada, and private sponsors provide the individuals with housing, financial support, and settlement assistance for their first year of residence in Canada. Organizations can hold agreements with IRCC to allow other groups to sponsor on their behalf. These organizations are called sponsorship agreement holders (sAHs), and the subgroups are known as constituent groups. SAHS are responsible for selecting their constituent groups, submitting immigration paperwork to IRCC, and guiding and supporting their constituent groups to provide quality integration support to refugees. The SAH and constituent groups are jointly responsible for the emotional and financial support of the refugees resettled under their agreements.

World University Service of Canada (wUSC) is a SAH that supports more than ninety campus-based constituent groups, known as wUSC Local Committees, to resettle approximately 130 refugee students to Canadian post-secondary institutions annually. Student members of local committees with support from faculty and staff (all referred to as local committee members) provide integration support to Student Refugee Program beneficiaries (the refugee students who are resettled to Canada through the program) and work to build more welcoming communities for newcomers by organizing public engagement activities on their campuses.

This article has a dual purpose: to assess the effectiveness of the Student Refugee Program's youth-to-youth sponsorship model in integrating former refugees into their receiving communities, and to share lessons learned and policy implications. ${ }^{4}$ We outline the impact of the Student Refugee Program upon its beneficiaries, and the important role youth volunteers play in supporting the integration process and in helping to build more welcoming communities for newcomers in Canada.

The evidence that supports this article's conclusions is drawn from a case study on groups of Student Refugee Program beneficiaries, local committee members, and alumni of both groups. Data were collected using a mixed methods approach: questionnaires, focus group discussions, and key informant interviews. This article will include a review of the literature on holistic newcomer integration and youth leadership in global issues, followed by a presentation of our methods and results. The discussion includes analysis of the results of the study in relation to the impact of the program on its beneficiaries and youth volunteers, as well as the broader community. Finally, we will share wusc's plans to scale up the program in Canada and recommendations for other countries and refugee resettlement programs regarding youth involvement in supporting the integration of resettled youth with a refugee background (herein referred to as refugee youth).

\section{Holistic Integration of Newcomers}

While refugees resettled to Canada arrive in safer environments than their home contexts, they face challenges upon settlement and throughout the integration process in Canada. Language proficiency in French or English is a primary challenge for newly arrived refugees, which is a barrier to obtaining appropriate employment, navigating the education systems and accessing higher education, and building social bridges within Canadian communities.

\section{Holistic Integration Model}

Over the past decade, researchers in Canada have focused primarily on the more traditional economic markers of "successful" integration such as type of employment, income, and poverty levels; however, there is a growing need to demonstrate the importance and role of social and systemic factors that influence overall integration success of refugee populations. In addition, there is a need to better understand the role that receiving communities play in creating welcoming and responsive communities to meet the needs of diverse refugee groups. Yu, Ouellet, and Warmington defined refugee integration as a "dynamic, multi-faceted two-way process which requires adaptation on the part of the newcomers, but also the society of the destination" on social, functional, and psychological levels. ${ }^{5}$ Ager and Strang built on this idea by developing the social integration model, which pushed the discourse beyond objective material markers to include other variables related to socio-economic context, such as language, culture and knowledge, and safety and security. ${ }^{6}$ While this model further refined past theories of refugee integration, it was limited in that it did not include refugees' sense of belonging to their new communities, institutional adaptation to refugee needs, or the holistic nature of the integration process.

Hynie, Korn, and Tao refined Ager and Strang's model to create the holistic integration model (figure 1). ${ }^{7}$ This model showcases how each of the factors relevant for strong integration found in Ager and Strang's theory (i.e., citizenship, language and cultural knowledge, safety and stability, social bonds, bridges and links, housing, education, employment, 


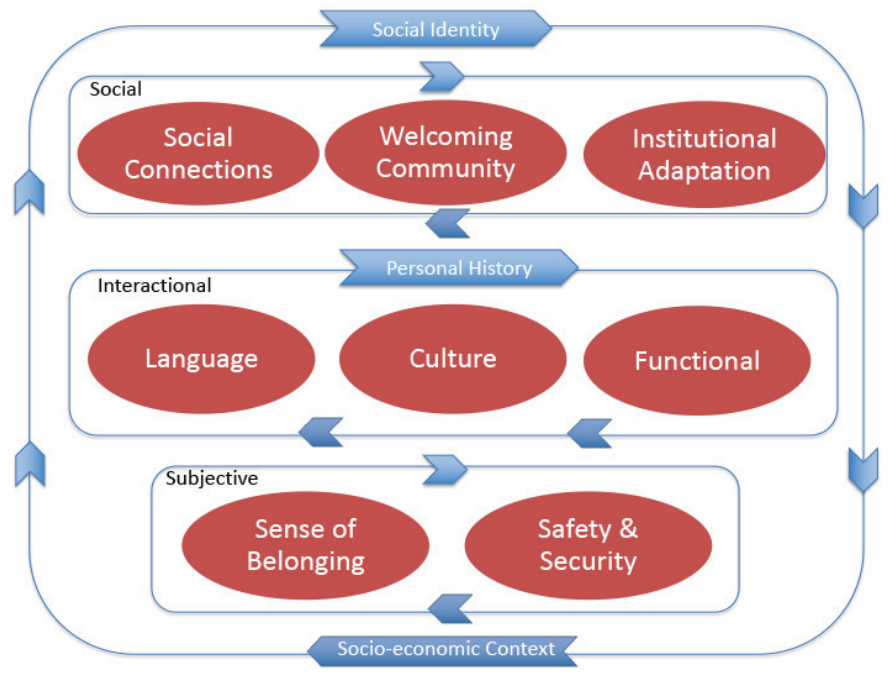

Figure 1. Holistic integration model

and health) are interdependent. These factors are grouped into three main categories: social identity (social connections, community welcome, institutional adaptation); personal history (language, culture, functional); and socioeconomic context (sense of belonging, safety, and security). Hynie, Korn, and Tao emphasize the essential role of the receiving communities and explain the interdependence of these categories as "the extent to which agencies, institutions, and communities accommodate refugee needs ... facilitate the functional aspects of integration [and] also create a feeling of welcome, thus affecting the integration process at the social and subjective, as well as functional levels."

The holistic integration model suggests that although refugees are required to build their skills and knowledge of the receiving community, such as language and socio-cultural practices, the receiving community must also support changes within institutions, systems, and social attitudes to accommodate refugee needs and experiences in order to achieve effective integration. ${ }^{9}$

\section{The Role of Youth: Integrating Refugees and Building Welcoming Communities}

The Student Refugee Program (SRP) is the only known youthto-youth refugee sponsorship model, attracting global attention. As such, the effect of youth-to-youth sponsorship on both refugee integration and youth sponsors themselves is an emerging topic of study. Despite this gap in the literature, we can draw on the broader research conducted on the role that youth can play as leaders in their communities to effect change. From this research we know that youth can be agents of positive and constructive change for global issues.
A United Nations subgroup states that youth can be innovators and active citizens, and argues that their activities are integral to building peaceful communities for all. ${ }^{10}$

The SRP engages a particular segment of youth: post-secondary students. Although there is no research on studentto-student refugee integration, the research on studentto-student mentorship for international students provides relevant evidence to draw from, despite the differences in experiences between international students and students with a refugee background. International students have chosen to leave their home country to study, may have social connections in their country of study, and have access to family networks and resources to fund their studies. Refugee experiences are grounded in fleeing conflict or persecution, and refugees often arrive in their country of resettlement with little to no financial capital and limited social networks. However, research on international students' experiences in their adaptation to their places of study within the country and local communities is relevant.

Shakya et al. found that newcomer students who have not received timely orientation and guidance can experience "confusion and misdirection" in their academic path." According to the United Nations report on youth and migration, when international students are well oriented to their academic institutions, they can have more positive academic and integration experiences: "Research has shown that international students provided with an initial orientation by their educational institutions tend to be much better prepared for their foreign academic experience and life abroad. Such support can make a critical difference to their adjustment to unfamiliar surroundings. A student migrant who feels disoriented or unwelcome is likely to have difficulty learning and is more vulnerable to risks within a new community."12

Not only are orientations important to international student success, but research has also shown that studentto-student mentorship schemes are particularly effective. Such schemes "have been found to aid social adjustment or enhance social support, improve academic achievement, and increase utilization of university services including counselling services" for international students. ${ }^{13}$ Thomson and Esses found that their mentorship pilot program resulted in improved socio-cultural and psychological adaptation for international students. ${ }^{14}$

\section{wUSC's Student Refugee Program: A Youth-to- Youth Sponsorship Model}

While many countries are developing community sponsorship programs, education schemes, and other forms of complementary pathways for refugees, WUSC's SRP is the only program that combines resettlement with higher education. 
wUSC Local Committees secure the funds required and support the integration of the refugee students upon their arrival. In addition to providing initial settlement and integration support to refugees on their campuses, local committee members also build more welcoming communities for newcomers by engaging their personal networks and the public on their campuses and in their communities through awareness-raising activities.

The SRP has two ultimate objectives: to help refugee students make meaningful contributions to their communities (locally and globally) and secure better lives for themselves and their families; and to build more welcoming communities for newcomers in Canada. For the SRP, more welcoming communities are aware of and responsive to refugee needs by adapting programs and policies to reduce barriers for refugees and newcomers, and create a sense of safety and belonging for newcomers. Students on local committees are particularly well placed to achieve these objectives. Their ability to provide comprehensive student-to-student academic and social support to SRP beneficiaries can help refugee students feel more welcome on campus and enable them to access the resources they need to improve their learning outcomes.

The SRP's student-to-student model provides a platform for engagement with other actors on campus, including administrators, faculty, and students outside the local committee. Local committees advocate for SRP beneficiaries' admittance to their post-secondary institutions by working closely with institutions' admissions offices and requesting flexibility on their admissibility requirements. By explaining the extenuating circumstances surrounding refugee students' documentation and language test scores, for example, local committees expose admissions offices to the unique needs and experiences of refugee students.

Another primary role of local committees is to engage the student body on their campuses on refugee issues, which in turn contributes to the financial sustainability of the program. Local committees leverage a sustainable funding mechanism unique to post-secondary institutions: the student levy. Student levies are small fees applied to the tuition and administrative fees of each student who attends a given institution. The SRP on campuses collects a levy from over one million Canadian students per year at an average of three dollars per student per year. This indirectly engages all contributing students in the SRP. Local committees also directly engage these students by running referendum campaigns to implement and increase the levy amounts and "thank you" campaigns for students' levy contribution on their campuses, to raise awareness about the levy and its impact on the lives of refugee youth on campus, along with other awarenessraising initiatives each school year.

\section{Methods}

In 2017 wUSC began to pursue an impact study as a followup to a study that was completed in 2007. One survey was designed and disseminated by WUSC to SRP beneficiaries to collect information on their educational pursuits and experiences, as well as their social and economic outcomes following their participation in the sponsorship program. wUSC also surveyed local committee members and alumni about their experiences with wUSC and the SRP specifically, and whether their participation in the program affected their civic engagement, their academic or career paths, or their long-term engagement on refugee issues. The surveys comprised multiple choice and Likert scale questions. wusc then contracted third party consultants to gain further insight on the findings through qualitative interviews (in the form of focus group discussions and key informant interviews) with program beneficiaries in February 2018.

The main objectives of the study were twofold: to assess the impact of the SRP on its beneficiaries with respect to their settlement and integration and what factors contribute to positive outcomes; and to assess the impact of the program on the local committee members and alumni on Canadian campuses, related to their role as private sponsors, and the impact their participation has had on their personal, professional, and academic paths and networks.

\section{Phase I: Impact Surveys}

The surveys gathered quantitative data on the impact of the program on SRP beneficiaries and local committee members and alumni. The survey study population comprised two groups.

SRP beneficiaries were university students who arrived in 2013 or earlier, and college/CEGEP students who arrived in 2014 or earlier $(N=192)$. The rationale for focusing on these respondents was that the majority of respondents who arrived in these years or earlier would have graduated at the time the survey was conducted in spring 2017.

Approximately 770 people were contacted to fill out the survey. Respondents numbered 250 and 192 gave complete responses. The response rate was approximately $34 \%$. More than 1,800 SRP students have participated in the program from its inception in 1978 until 2017, therefore about $10 \%$ of all program participants between 1978 and 2017 fully completed the survey.

Local committee members and alumni were students, staff, and faculty members who have been members of a local committee $(N=135)$.

Approximately 4,100 people were contacted to fill out the survey. Respondents numbered 265 and 135 gave complete responses. The response rate was therefore approximately $6.6 \%$. 


\section{Table 1. SRP respondent demographics}

Gender breakdown

139 male, 52 female, 1 prefers

not to say

Year of arrival in Canada

by decade

1980 (9), 1990 (21), 2000 (87),

Province of sponsoring

institution
2010-14 (75)

$B C(27), A B(6), S K(16), M B(13)$,

ON (92), QC (13), NS (21), NB (1),

PEI (1), NL (2)

Participants from both populations were recruited for the study via the program database e-mail contact list, social media, and through word of mouth. The sample was not representative, as all prospective study participants were contacted based on the availability of their current contact information, and not according to a probability sampling technique. All alumni that fit the criteria of the study were asked to fill out the survey. Due to an incomplete list of alumni contact information in the program database, response rates were low.

\section{Phase II: Focus Groups and Key Informant Interviews}

Qualitative approaches, including individual interviews and focus groups, were used to examine and better understand findings from the survey data analyses. A letter of invitation was emailed to all the SRP beneficiaries and local committee members and alumni that wusc had on file. Twenty-one individual interviews and one focus group with four participants were conducted with SRP beneficiaries. Sampling criteria included gender, university and college/CEGEP alumni, region of sponsorship, and current location. The majority of interview respondents had been in Canada for less than five years.

Eight individual interviews and one focus group with four participants were conducted with local committee members and alumni. Efforts were made to select participants who reflected different roles on the committee, type/size of institution, language, and location. Of the twelve local committee members and alumni who participated in the interviews, eight participants were students and four were faculty or staff at the time of their involvement.

Individuals took part in a semi-structured interview or a focus group. All interviews were conducted in English, except for one conducted in French. The interviews were conducted over the phone and were recorded. Each interview lasted from forty-five to sixty minutes. The focus group was conducted using a teleconference line allowing for multiple participants.

\section{Table 2. Local committee respondent}

demographics

Gender breakdown

94 female, 44 male, 3 prefer not

to say

Year of participation

on local committee by

decade

Before 1980 (1), 1980 (1), $1990 \mathrm{~s}$

(5), 2000s (40), 2010-17 (87), no

answer (1)

Member type no answer (2)

wUSC and the consultants developed an interview guide in keeping with a grounded theory approach. The interview guide questions highlighted the experiences of the SRP beneficiaries and gathered information about their objective and subjective integration outcomes. A research assistant supported the coordination, delivery, and transcription of the interviews. The interviews were recorded and transcribed. Axial coding was used to identify themes and codes related to participants' experiences.

\section{Strengths and Limitations}

A case study approach was used, which did not allow for the collection of data that could be extrapolated to a larger population. As discussed above, the survey response rates were low and the sample was not representative of the population of program participants.

Response bias is another potential limitation of the study: for example, participants may have framed their experiences with the SRP in a positive light because the program helped them in the past. Alternatively, it is possible that participants felt they could share their experiences even if they were negative, as a result of their trust in and comfort with wUSC, and the amount of time that had passed for some individuals since taking part in the program.

The sample may have been biased because it may have not have included the population of SRP beneficiaries who are not doing as well. The study was conducted anonymously, and limited demographic information was collected, so it was difficult to uncover trends within the sample. The reason for this approach was to ensure that participants felt comfortable providing feedback about the program while remaining anonymous, thus supporting the participation of as many respondents as possible.

Despite these limitations, the strength of a case study approach is its ability to provide an in-depth exploration of a topic: in this case, participants' experiences with the SRP. Although the data are not generalizable to a larger population, they provide insight into the program's impact on this 
small group of individuals. The study also highlights areas for further research on the integration experiences of resettled refugees in Canada (discussed in the Conclusion).

\section{Results: SRP Beneficiaries}

\section{Completion of Education}

The results of the case study show that $94 \%$ of surveyed SRP beneficiaries completed a degree after their arrival in Canada, and $80 \%$ completed their degree at their original sponsoring institution. Few (11\%) study participants experienced interruptions in their studies after arrival in Canada, with $64 \%$ of those who did experience an interruption returning to their studies later. Key barriers associated with interruptions to study included the cost of living, cost of studies, family obligations, or illness. Among the survey respondents, 55\% had pursued or are pursuing further education beyond their first studies completed in Canada.

\section{Access to Employment Opportunities and Skills Development}

The interviews with SRP beneficiaries indicate there is a connection between education and employment outcomes.

Education ... gives me the job I have now [and] the freedom and power and mindset to have everything that I have. In a big way. - SRP beneficiary, interview

Two-thirds of respondents indicated they are satisfied with their jobs, with job satisfaction increasing in relation to the number of years spent in Canada. As seen in figure 2, the majority of SRP respondents who arrived in Canada ten or more years ago are satisfied with their jobs.

The case study also revealed, through the qualitative interviews, that local committee members were key to connecting SRP beneficiaries to job opportunities on and off campus, and thus contributed to their later employment outcomes:

It was helpful. I was working at the library of the university. The members of wUSC were instrumental in helping me get that job. I told them that I wanted a job and they went around and basically got me a job at the library. It was very helpful, a lot of customer service helping students at the university. The skills that I got in that first job were transferable to all of my other jobs. - SRP beneficiary, interview

When I was at school the local committee found me my first job in Canada at the college library.... [From] second semester until graduation I worked there. I gained experience in all areas, especially language.... [My] English was not that good. So the more exposure to students, it boosted my language ... I made so many connections through my campus job. I had a lot of friends, and I was making money. —SRP beneficiary, interview

A common theme among the SRP beneficiary interviews is the importance of networking and social and professional connections for their integration. Local committees connecting SRP beneficiaries with jobs on campus, helpful references from professors when applying to postgraduate education programs, and the sponsoring community's role in contributing to a strong sense of belonging were some of the examples provided by interview respondents.

\section{Sense of Belonging and Navigating Services}

Seventy per cent of SRP beneficiaries who responded to the survey reported a strong sense of belonging to Canada overall, as well as their family ( $87 \%)$, city $(81 \%)$, ethnic community (69\%), and neighbourhood (69\%).

I feel part of the general community. I am a citizen now. I feel ... that I belong somewhere. It makes me feel proud. I feel real belonging. - SRP beneficiary, interview

SRP was a foundation-having that first family that show you everything you need to know... That was my foundation. I had a family that loved me ... [and] helped to get into bigger Canadian setting. - SRP beneficiary, interview

Interview participants indicated they feel "at home" where they live and are "proud Canadians"; many attributed this feeling to the support of their local committee when they first arrived, as well as connections to community.

Students who were resettled in small communities felt a sense of belonging even where their ethnic community was largely absent. Overall, respondents reported that the social support of members of their ethnic community and former SRP students with a similar lived experience contributed to their safe and supportive transition to Canadian society. There was evidence of bridges and bonds built, as respondents reported strong friendships both within and outside of their ethnic communities. SRP beneficiaries overwhelmingly (92\%) describe Canadians as "welcoming and accepting."

While many SRP beneficiaries reported in interviews that they had experienced homesickness and missed their families, many were also able to build family-like relationships in Canada with their sponsoring community. Some interview participants described long-term friendships with those they referred to as their "Canadian parents" (families who had supported them since their arrival in Canada). Even after moving across the country, some respondents make annual trips to their original city of residence in Canada to 


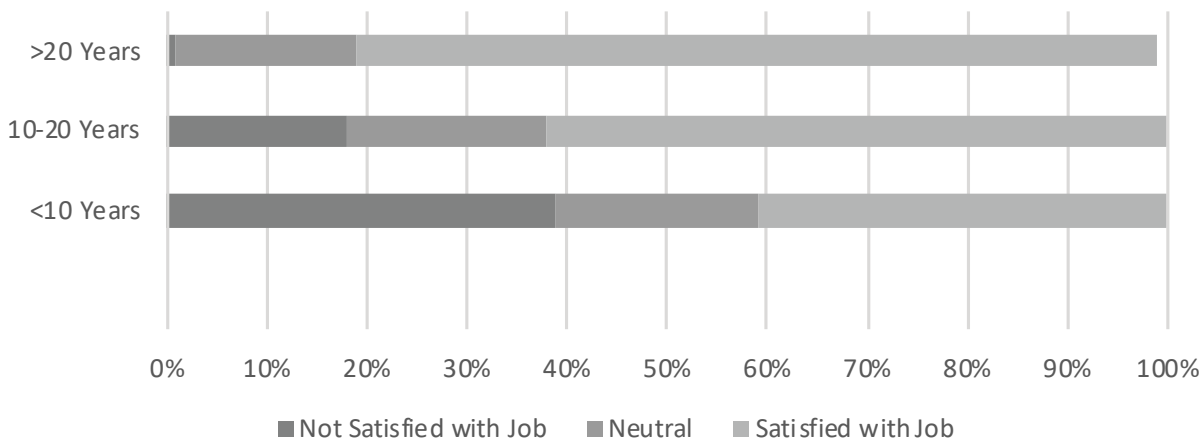

Figure 2. SRP beneficiaries' job satisfaction according to the number of years spent in Canada

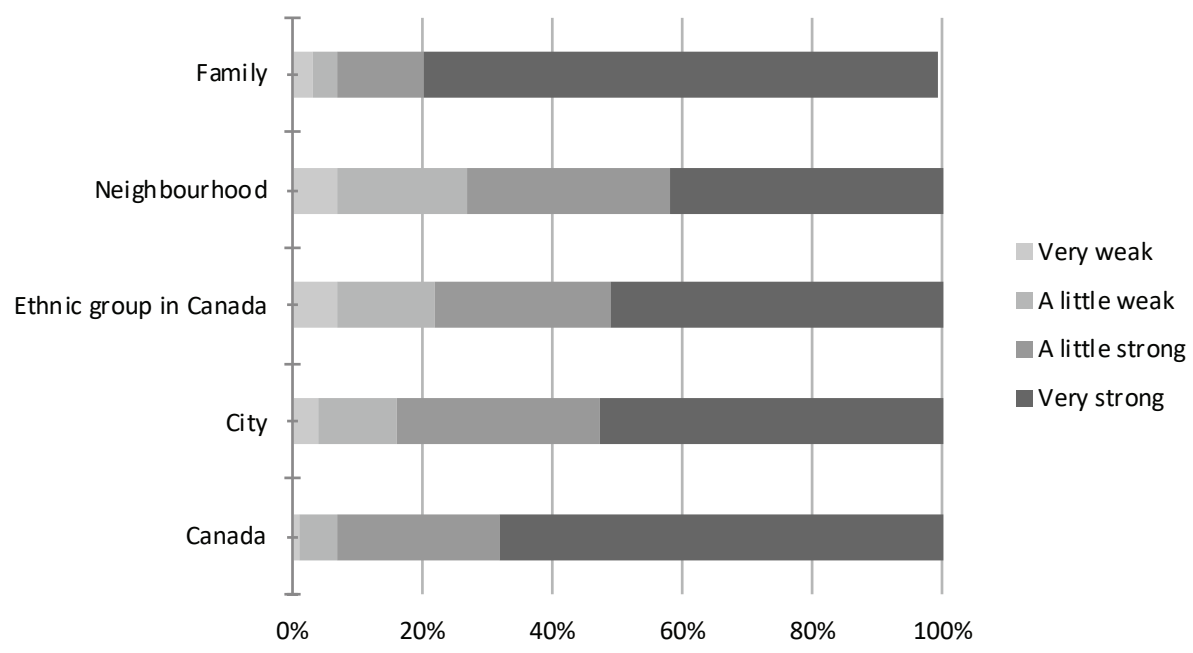

Figure 3. SRP beneficiaries' sense of belonging

visit their first friend and family networks. They expressed deep gratitude for the openness and support provided, particularly during their initial settlement:

My initial contact was the local committee. Some of these people became friends throughout university.... The [local committee] coordinator became a main support.... In my third year I actually moved into her house. She became like a mother figure.... The last two years I stayed at her place.... I still stay in touch with her.... She's Canadian white, we're different in all aspects, but we're still connected. There are some amazing people in a small town that you can connect with more than in a bigger city. -SRP beneficiary, interview

I feel like I absolutely belong. I do belong here. It's my home.... I don't think there is any freedom anywhere like in Canada.... wUSC connected me with two boys from [my country of asylum] in [my city of resettlement], and they were like brothers for me. They took me into the mosque. The local community takes you in and welcomes you. The community ... feels like a different country. My friends are from all over the world. I met them through work and school. —SRP beneficiary, interview

The majority $(87 \%)$ of SRP beneficiaries who responded to the survey feel that they have adapted to Canadian society. A further $82 \%$ feel accepted and $80 \%$ feel respected in their community. However, approximately two-thirds of survey respondents indicated they have experienced and/or witnessed racism while in Canada. One-quarter of interview respondents reported experiences of discrimination due to their immigrant status, race, religion, name, accent, and in some cases gender. This was specifically related to experiences searching for employment in their communities. The role of local committee members is to support students while they navigate and overcome these experiences and challenges during the sponsorship. The interview data illustrate that local committee members contribute to creating a welcoming environment, but this does not prevent SRP 
beneficiaries from experiencing discrimination similar to other immigrant groups.

Interview participants overwhelmingly expressed a desire to "give back to the community" after their sponsorship, either with time or financial contributions. Some are involved in charity work through their churches, and/or supported youth-serving or immigrant-centred agencies and NGOS. Other SRP beneficiaries are active in charity work within their ethnic communities, in Canada and back home, while still others are part of broader community engagement.

I spent last night watching Canadian women's hockey and stayed awake until 1:30 a.m. I feel connected to the community and country. I feel connected to the politics at the provincial and federal level elections. I follow everything. I accepted that it is my home and to stay here and experience everything Canadians experience.... I voted and participated in elections-federal, provincial, municipal... If you want to change things, you can't just ignore, you have to be heard to have an impact. I think after almost six years in [city of residence], I feel a connection. This is my city." - SRP beneficiary, interview

When I was at university I used to volunteer at [the] hospital. I volunteered at so many places.... I feel like I'm part of a community. -SRP beneficiary, interview

When I was a student I volunteered. It contributed to a sense of belonging.... I have the freedom to vote in an election. An incredible experience to choose your leader... You will learn to appreciate every single day you spend here. - SRP beneficiary, interview

The above examples show the diverse ways in which SRP beneficiaries have involved themselves in the community, from voting in elections to volunteering. Many prioritized volunteering even during their studies, and it made them feel a sense of belonging to their community.

\section{Results: Local Committee Members}

\section{Academic and Career Path}

More than half $(57 \%)$ of survey respondents who were students when they were on a local committee indicated that they felt that being on the committee influenced their decision to pursue courses related to global issues. A further $77 \%$ reported that their overall academic experience was improved by their involvement on a local committee.

Ultimately it ignited my passion to pursue a career in immigration and newcomer settlement. I did a master's in immigration settlement. I am an English teacher. It has played a part in all areas of my life. It has lasting impact in what I do today. - Local committee alumnus
Not only did being part of a local committee affect their academic experience while on the committee; $40 \%$ also indicated it influenced their decision to pursue additional studies. Involvement on a local committee also affected $57 \%$ of students' career paths. Local committee members demonstrate sustained engagement in refugee issues in their personal and professional lives, as is evident below.

\section{Continued Involvement in Newcomer Issues}

The majority (77\%) of local committee members and alumni who responded to the survey remained connected with SRP students, indicating that strong relationships were built among the students during (or in some cases outside) the sponsorship. Local committee members and alumni have also been involved (29\%) or somewhat involved (14\%) in supporting refugee and newcomer settlement and integration beyond their work with the SRP. Of survey respondents who voted in elections, $98 \%$ indicated that policies that promote the protection, inclusion, and integration of refugees inform how they vote. All local committee respondents indicated they have volunteered or worked at settlement agencies, community centres, libraries, and mentorship programs that connected them directly to newcomers.

I am an advocate in immigrant/refugee issues [and] I am involved with the asylum seekers in Manitoba. -Local committee alumnus

Approximately $20 \%$ of local committee members who responded to the survey reported that they are or had been part of a group that participated in private sponsorship of refugees outside the SRP. For example, one interview participant was part of a Group of Five working to sponsor Syrian refugees. In addition, one in four respondents indicated that they have worked to support the inclusion of newcomers in the workplace or the broader labour market. More than twenty examples of these efforts were described by respondents, including hiring former refugees or recommending them to their employers, providing language instruction, helping with résumés, creating clubs and social events aimed at inclusivity, and more.

\section{Results: Broader Canadian Community}

Local committee members and alumni are having an impact on their community by voting in elections and volunteering in newcomer programs. They also work to influence their professional and social networks to be more aware and knowledgeable of refugee issues and needs. Local committee members and alumni reported increased awareness about forced migration issues from their efforts to engage their broader networks. This is evident in figure 4, where respondents indicated they had increased awareness of 


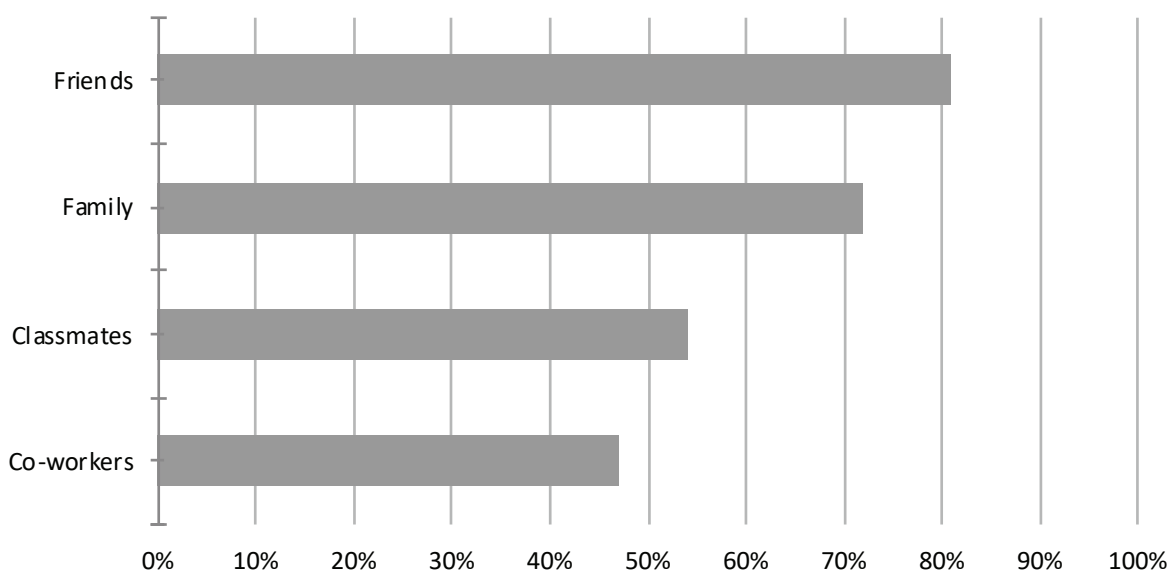

Figure 4. Increased awareness among local committee alumni networks

forced migration in the networks of friends (81\%), family ( $72 \%)$, classmates $(54 \%)$, co-workers (47\%), and faith groups (11\%).

As demonstrated in the holistic integration model (figure 1), mutual adaptation to the needs and experiences of refugee populations by receiving communities is essential to building welcoming environments for refugee populations. Local committee members and alumni across Canada are strengthening public awareness of and engagement in forced migration issues among their personal and professional networks, thus contributing to building a mutually adaptive society.

\section{Discussion}

\section{Impact on Program Beneficiaries}

The results of this study show that a youth-to-youth sponsorship model can effectively integrate refugees socially and economically into Canadian society. The findings illustrate that the program model contributes to the creation of more welcoming communities, through awareness-raising activities and the trickle-down effect from local committee members' broader networks.

Resettling refugee youth in Canadian post-secondary institutions reduces many barriers to integration faced by other refugee youth, such as providing access to education, language training, and employment opportunities. It is important to acknowledge that SRP beneficiaries begin their integration at a place different from other refugees arriving in Canada. To be eligible for the program they have strong language skills in English or French, have completed secondary education, have access to some academic documentation, and are immediately enrolled in Canadian post-secondary institutions as part of the program. As shown by the holistic integration model, this would affect their ability to integrate quickly.
The study results demonstrate the interconnectedness of integration outcomes for refugees that can lead to positive integration experiences, as illustrated in the holistic integration model. Local committee members support SRP beneficiaries academically, helping them navigate the education system and access on-campus academic support services. The findings reveal the positive outcomes of this support: the majority of SRP beneficiary survey respondents completed their degrees in Canada, and more than half pursued additional education at universities and colleges in Canada. According to the interviews with SRP beneficiaries, academic success and local committee support contributed to accessing satisfying employment at different stages of their career. Many SRP beneficiaries found their first jobs on campus with the support of the local committee members. These first jobs helped build Canadian experience on students' resumés, improved their language skills, and connected them to other employment opportunities and networks.

Having skills, tools, and networks upon arrival and early on in the integration process supports refugee youth to achieve positive integration outcomes, including feeling a sense of belonging to their receiving communities. SRPbeneficiaries described local committees as their "Canadian family" who played a key role in making them feel welcome in their community, particularly in the first months. This sense of belonging is also reflected by the fact that many SRP beneficiaries felt the desire to "give back" to their communities through volunteer and financial efforts.

\section{Impact on Communities}

Early engagement of local committee members with newcomers and the issues they face leads to long-term involvement through work, volunteer, and civic efforts to support 
newcomer integration in their communities, including influencing their voting considerations in elections. Their participation also influences their choices in working and volunteering with newcomer programs and sponsoring refugees beyond the SRP. The SRP provides opportunities for new youth volunteers to get involved each year as new students begin their studies at post-secondary institutions.

As discussed in the literature review, youth are uniquely positioned as innovative leaders who can mobilize their peers and community on global issues. While youth in local committees are directly involved in and transformed by refugee sponsorship through the SRP, this impact extends beyond the local committee members. As local committee members engage their communities through events on campus and provide integration support to SRP beneficiaries, the wider community becomes more aware of refugee issues and how they can support newcomers. This is demonstrated through the institutional adaptation seen in refugee student admissions at receiving institutions. Local committee efforts are directly reducing barriers and making post-secondary communities more aware of the barriers while offering solutions to overcome them. These students go on to inform more institutional adaptation, as they engage their places of employment, family, friends, and other personal networks.

\section{Lessons Learned and Further Research}

wUsc's model of combining education and youth-to-youth refugee integration aims to achieve the objectives of the holistic integration model as outlined by Hynie, Korn, and Tao. The quantitative and qualitative results of the case study show that the SRP addresses many of the desired outcomes outlined in the holistic integration model to ensure that resettled refugees can start their new lives in Canada with a strong foundation, leading to positive long-term integration. Although selection criteria of the program may also contribute to successful integration, it is clear that youth-to-youth model enhances integration and creates more welcoming communities as a result of the work of local committees to engage their peers and communities on and off campus.

Personal experiences with refugee sponsorship can have a positive impact upon perceptions of those working with refugees through the SRP. These experiences often result in local committee youth's long-term commitment to global issues and acting as change agents to create more welcoming communities. In addition, raising awareness builds welcoming communities among the campus and community stakeholders surrounding the sponsoring group. Further study is required to explore if there is an impact on the broader networks of local committee members and alumni, through changes in behaviours, perceptions, and actions related to reducing barriers for refugees and newcomers in Canada, and engagement in other forced migration issues.

Further research on refugee integration is also needed, particularly on the peer-to-peer refugee integration models that connect refugees and sponsors based on identity factors such as LGBTQ identities. As more research is done in Canada that applies the holistic integration model for resettled refugee groups, it is imperative that this research focuses on whether youth-to-youth or peer-to-peer sponsorship models would result in more effective integration and build adaptive receiving communities. In addition, research comparing the SRP to other models in private sponsorship would be helpful to better contextualize the program's strengths and areas for improvement. More research needs to be done on welcoming communities: how they are created, SRP beneficiaries' experiences in these communities (including experiences of racism and how local committees can support students to navigate these experiences), and the role of community engagement on societal and institutional change. The SRP plans to strengthen its capacity to monitor more longitudinal outcomes of the program on the stakeholders and beneficiaries, as well as broader Canadian communities.

Overall, the research conducted on the SRP has elucidated some lessons about youth leadership in refugee integration. We know that local committee members play a key role in supporting SRP beneficiaries to navigate academic and oncampus systems that help them begin their academic career positively and contribute to their completion of their education. Local committee members also support SRP beneficiaries' access to employment by connecting them to their first jobs on campus and to different networks on and off campus to build experience on their new Canadian resumés, which links to later employability. In many cases, local committee members form strong bonds with SRP beneficiaries, as they are the first to welcome them to their new community and are of a similar age group. This contributes to SRP beneficiaries' later sense of belonging to their communities. Local committee members also demonstrate long-term engagement in refugee and global issues through their voting practices, volunteer work, and advocacy for newcomers in their workplaces. As a result of these lessons, wUsC recommends that other refugee sponsorship groups consider implementing a youth-to-youth or peer-to-peer model.

\section{Future Directions for the SRP}

While the SRP is a successful model of refugee integration in Canada and reaches thousands of Canadians each year, either directly or through public engagement events, the number of refugees resettled (130 per year) is small relative to global need. wUSC is reaching out to new post-secondary partners 
in college and CEGEP networks to provide more placements for refugee students, while supporting long-time partner institutions to sponsor more students. Colleges and CEGEPS provide unique opportunities for students to access language programs, flexible admissions requirements, and often faster pathways to employment after completion. Between 2017 and 2019, wUSC welcomed an additional twenty-two institutions to its network, offering thirty-nine new placements for refugee students.

With the success of the SRP model in Canada, wUSC is also sharing the model internationally, as other countries develop education and resettlement schemes in commitment to new principles for refugee protection and integration. The United Nations Global Compact on Refugees, adopted by the UN General Assembly in December 2018, outlines commitments to several principles that are well aligned with the SRP. The document emphasizes "a multi-stakeholder and partnership approach" that includes refugee and receiving community members, development actors, cities, public-private partnerships, and academic networks, among others. ${ }^{15}$ The SRP is compatible with this "whole of society" approach to refugee protection and education, and thus engages all of these actors, often through the work of young local committee members.

The compact emphasizes the empowerment of refugee and receiving community youth to build "their talent, potential and energy" to support eventual solutions. ${ }^{16}$ The compact indicates that states and relevant stakeholders should "utilize and develop" youth capacities and skills, and facilitate youth networking and information sharing, which is in keeping with the SRP mandate to create welcoming communities. ${ }^{17}$ wUSC has a long tradition of encouraging youth to share best practices in refugee sponsorship and public engagement regionally and nationally. wUSC is working expanding this network transnationally in partnership with student groups in Europe.

The compact also highlights the importance of complementary pathways for refugees, in particular through educational opportunities through partnerships with governments and academic institutions. ${ }^{18}$ The inclusion of education in the compact emphasizes its importance as a complementary pathway to durable solutions and mechanisms through which refugees can become part of and maximize their contributions to communities. As more community sponsorship schemes are developed in response to the recommendations from the compact (which is led by the UNHCR with buy-in from member-states and civil society), education will increasingly be seen as a key component of facilitating integration.

\section{Conclusion}

wUsc's Student Refugee Program, in partnership with academic institutions across Canada, provides pathways to resettlement for refugees through education, as well as an opportunity for young refugees to effectively integrate into increasingly welcoming communities in Canada. This integration and welcoming is facilitated not only by education itself, but by the youth involved in the program's youth-toyouth sponsorship model. Youth studying at post-secondary institutions support refugee students' integration on campus and in their community and share their experiences with those around them to build more welcoming communities for newcomers. With over forty years of experience in these areas, wUSC is seen as a global leader with lessons to share on youth-to-youth and peer-to-peer sponsorship models. While the SRP's daily operations differ from campus to campus, wUSC is able to recommend standard practices that can apply across the campus network, including the student levy funding model. wUSC recommends that more countries consider models of sponsorship and education programs similar to the SRP in their plans for fulfilling the recommendations of the compact.

\section{Notes}

1 GovernmentofCanada, "ResettledRefugees-MonthlyiRCC Updates," last modified 12 March 2018, https://open.canada .ca/data/dataset/4a1b26oa-7ac4-4985-8oao-6ozbfe4aec11.

2 It should be noted that forced migrants also arrive to Canada over land and make claims for refugee status upon arrival. These refugee claimants are not eligible for resettlement assistance but can access some government programs and services while they await determination of their status.

3 Refugees who arrive to Canada through the GovernmentAssisted (GAR) or Blended Visa Office-Referred (BVOR) Programs are referred by the United Nations High Commission for Refugees or another referral organization and are financially supported by the government for between six (BVOR) and twelve (GAR) months. Social support comes from government-funded settlement agencies (GAR) or from groups of private citizens (BVOR).

4 This article updates and broadens the scope of scholarship from Robyn Plasterer, "Investigating Integration: The Geographies of the wUSC Student Refugee Program at the University of British Columbia," Refuge 27, no. 1 (2010): 59-74, which focuses on outcomes for students at the University of British Columbia; and Glen Peterson, "Education Changes the World': The World University Service of Canada's Student Refugee Program," Refuge 27, no. 2 (2012): 111-21, who outlines the history of the program. Wong (2013) discusses resilience among four SRP beneficiaries and how wUSC Local Committees and institutions can support integration.

5 Soojin Yu, Estelle Ouellet, and Angelyn Warmington, "Refugee Integration in Canada: A Survey of Empirical Evidence and Existing Services," Refuge 24, no. 2 (2007): 17. 
6 Alastair Ager and Alison Strang, "Understanding Integration: A Conceptual Framework," Journal of Refugee Studies 21, no. 2 (2008): 166.

7 Michaela Hynie, Ashley Korn, and Dan Tao, "Social Context and Integration for Government Assisted Refugees in Ontario, Canada," in After the Flight: The Dynamics of Refugee Settlement and Integration, ed. Morgan Poteet and Shiva Nourpanah (Newcastle upon Tyne: Cambridge Scholars Publishing, 2016), 188.

8 Hynie, Korn, and Tao, "Social Context and Integration," 187.

9 Jennifer Hyndman and Michaela Hynie, "From Newcomer to Canadian: Making Refugee Integration Work," Policy Options, 17 May 2016, http://policyoptions.irpp.org/ magazines/may-2016/from-newcomer-to-canadianmaking-refugee-integration-work/.

10 United Nations Inter-Agency Network on Youth Development, "Guiding Principles on Young People's Participation in Peacebuilding," 2014, 1.

11 Yogendra B. Shakya, Sepali Guruge, Michaela Hynie, Arzo Akbari, Mohamed Malik, Sheila Htoo, Azza Khogali, Stella Abiyo Mona, Rabea Murtaza, and Sarah Alley, "Aspirations for Higher Education among Newcomer Refugee Youth in Toronto: Expectations, Challenges, and Strategies," Refuge 27, no. 2 (2010): 71.

12 United Nations, "Youth and Migration Report," 2013, 68.

13 Rachel A. Smith and Nigar G. Khawaja, "A Review of the Acculturation Experiences of International Students," International Journal of Intercultural Relations 35 (2011): 708.

14 Clint Thomson and Victoria M. Esses, "Helping the Transition: Mentorship to Support International Students in
Canada," Journal of International Students 6, no. 4 (2016): 881.

15 United Nations High Commission for Refugees, "The Global Compact on Refugees (draft 3)," 4 June 2018, 7 , http://www.unhcr.org/events/conferences/5b1579427/ official-version-draft-3-global-compact-refugees-4-june2018.html.

16 UNHCR, "Global Compact," 15.

17 UNHCR, "Global Compact," 15.

18 UNHCR, "Global Compact," 18.

Carolyn McKee is a program officer, Student Refugee Program \& Campus Engagement at the World University Service of Canada (wUSC). She can be reached at cmckee@wusc.ca.

Lee-Anne Lavell is the former coordinator, Student Refugee Program \& Campus Engagement at the World University Service of Canada (WUSC). She can be reached at lavell.leeanne@ gmail.com.

Michelle Manks is the senior manager, Durable Solutions for Refugees at the World University Service of Canada (WUSC). Shecan be reached at mmanks@wusc.ca.

Ashley Korn is the manager, Student Refugee Program \& Campus Engagement at the World University Service of Canada (WUSC). She can be reached at akorn@wusc.ca. 